\title{
Preliminary Qualitative Analysis and Implications of Wood Products Perception on Social Media
}

\section{Preliminarna kvalitativna analiza i posljedice percepcije drvnih proizvoda u društvenim medijima}

Preliminary paper • Prethodno priopćenje

Received-prispjelo: 20. 10. 2019.

Accepted-prihvaćeno: 28. 4. 2020.

UDK: $630 * 72$

https://doi.org/10.5552/drvind.2020.1962

(C) 2020 by the author(s). Licensee Faculty of Forestry, University of Zagreb. This article is an open access article distributed under the terms and conditions of the Creative Commons Attribution (CC BY 4.0) license.

\begin{abstract}
The article presents the results of the qualitative research of social media, managed by the Institute of the Civil Society, University of Ss. Cyril and Methodius in Trnava, in cooperation with the Slovak University of Technology in Bratislava. The research aimed to analyse different areas of the current management challenges and their perception of the selected social networks. The study concentrates on the presentation of the chosen manufacturers of the automotive industry and furniture industry on social media. The content analysis was based on the VADER (Valence Aware Dictionary and Entiment Reasoner) lexicon that was explicitly tuned to sentiments expressed in social media and QDA software.
\end{abstract}

Key words: automotive industry; qualitative analysis; sentiment analysis; social media; furniture industry

SAŽETAK・U članku su prikazani rezultati kvalitativnog istraživanja društvenih medija koje je proveo Zavod za civilno društvo Sveučilišta Svetog Ćirila i Metoda u Trnavi u suradnji sa znanstvenicima Slovačkoga tehnološkog sveučilišta u Bratislavi. Cilj istraživanja bio je analizirati različita područja aktualnih menadžerskih izazova $i$ njihovu percepciju na odabranim društvenim mrežama. Studija je koncentrirana na prezentaciju proizvoda izabranih iz automobilske industrije i industrije namještaja u društvenim medijima. Analiza sadržaja temeljila se na leksikonu VADER (Valence Aware Dictionary and Entiment Reasoner), koji je eksplicitno utemeljen na dojmovima izraženim u društvenim medijima i na QDA softveru.

Ključne riječi: automobilska industrija; kvalitativna analiza; analiza dojmova; društveni mediji; industrija namještaja

\footnotetext{
${ }^{1}$ Authors are assistant professors at Institute of Management, University of Ss. Cyril and Methodius in Trnava, Trnava, Slovak Republic.

${ }^{2}$ Author is assistant professor at Department of Physics, Faculty of Civil Engineering, Slovak University of Technology in Bratislava, Bratislava, Slovak Republic.

${ }^{3}$ Authors are assistant professor and PhD student at Institute of Industrial Engineering and Management, Faculty of Materials Science and Technology in Trnava, Slovak University of Technology in Bratislava, Trnava, Slovak Republic
} 


\section{INTRODUCTION}

\section{UVOD}

Social networking through online media can be understood as a variety of digital sources of information that are created, initiated, circulated, and consumed by Internet users as a way to educate one another about products, brands, services, personalities and issues (Chauhan and Pillai, 2013). As stated in the research of Enginkaya and Y1lmaz (2014), social media integrates consumers with their own voice, not as passive respondents in their relationships with brands as in the past, rather as active members of brand communities (Miller and Lammas 2010). These attributes enable brands to reach the right people, in the right place and at the right time (Schivinski and Dabrowski, 2016). According to Karlíček and Král (2011) cited in Čeněk et al. (2016), the most notable positive qualities of online marketing are the possibility of precise consumer targeting, personalisation, interactivity, multimedia content, simple efficiency measurement, and relatively low costs. Marketing the brands through social media is becoming precise, personal, interesting, interactive and social (Sri et al., 2011). During the last five years, social media in marketing has become a subject of many studies and interests (see Figure 1 representing the worldwide search interest on Google).

This study demonstrates partial results from the research conducted by the Institute of Civil Society, University of Ss. Cyril and Methodius in Trnava. The research is oriented to the qualitative analysis of social media and their utilisation by different industries. Firstly the qualitative analysis was applied for the automotive industry (Slovakia is the leading car producer per 1000 habitants in the world). The results of the qualitative analysis have been published in Babčanová et al. (2019) and Šujanová et al. (2019). This qualitative analysis has been extended to the comparative analysis between the automotive industry and selected producers of the consumer durables like furniture or electronics.

Presented results of the text content analysis of the selected social media for the furniture industry are based on one-week data collection (tweets) and customer comments published on YouTube for selected manufacturers. The content analysis was based on the VADER (Valence Aware Dictionary and Entiment Reasoner) lexicon that was explicitly attuned to sentiments expressed in social media (Hutto and Gilbert, 2014) and QDA software (MAXQDA).

This paper is divided into the following sections: The first part presents a literature review supporting the conceptual framework of the study. The second part is dedicated to the description of the research methodology as well as applied tools and data sources. The third part contains the results of the quantitative analysis of the social media content and comparison of the two selected industries. The final section provides the author's conclusion about the research results.

\section{MATERIALS AND METHODS 2. MATERIJALI I METODE}

The goal of the research was to analyse the content of the selected social media and compare the results for two different industries. Data collection was made using:

- Social media: YouTube and Twitter. The used QDA software influenced the selection of the media.

- Industries: Automotive and furniture industry. Previously conducted studies influenced the selection of these industries.

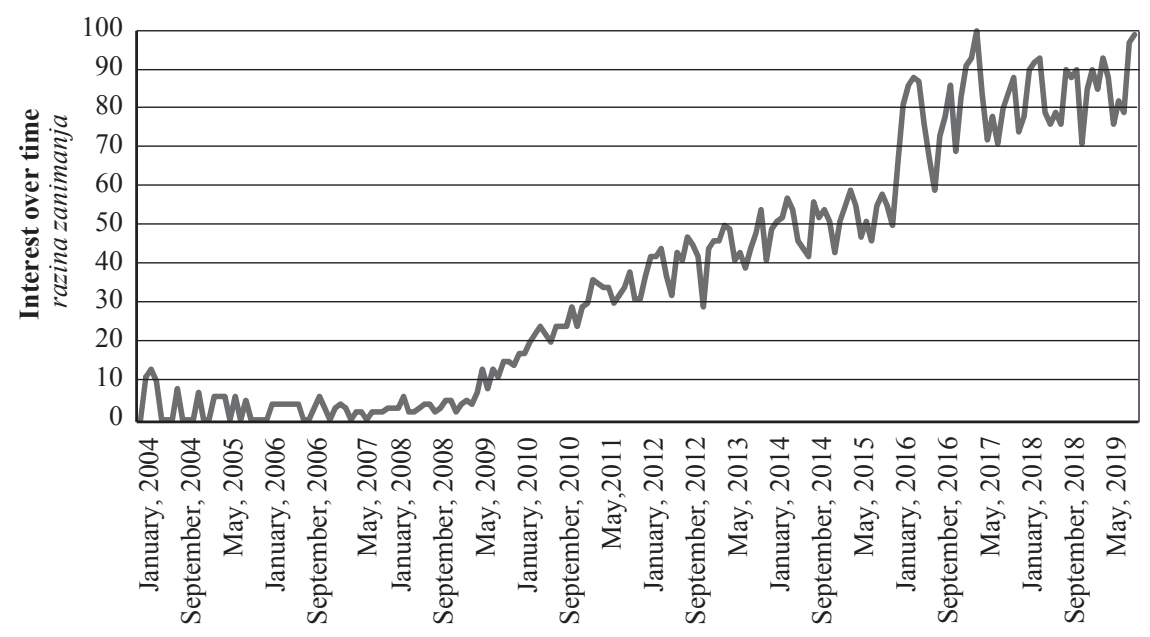

Note: Numbers represent search interest relative to the highest point on the chart for the given region and time. A value of 100 is the peak popularity for the term. A value of 50 means that the term is half as popular. A score of 0 means there was not enough data for this term. / $N a$ pomena: Brojevi predstavljaju interes za pretraživanje u odnosu na najvišu točku na grafikonu za datu regiju $i$ vrijeme. Vrijednost 100 je najveća popularnost pojma. Vrijednost 50 znači da je pojam upola manje popularan. Ocjena 0 znači da nije bilo dovoljno podataka za taj pojam.

Figure 1 Worldwide interest over time in the term of "Social Media in Marketing" Source: Google Trends

Slika 1. Globalno zanimanje za pojam društveni mediji u marketingu tijekom vremena (izvor: Google Trends) 
Content analysis:

- Data sources: YouTube and Twitter

- Data collection:

- Seven days of tweets collection filtered according to the selected automotive and furniture manufacturers in Europe.

- Visitors' comments on YouTube presentations of the selected automotive and wood furniture manufacturers in Europe.

- Data analysis tools: MAXQDA software

- Content analysis methodology: Sentiment analysis with the lexicon-based approach (dictionary-based approach) (Pawar et al., 2015).

Analysed manufacturers:

- Car manufacturers: Lexus, Renault, SEAT, Peugeot, BMW.

- Furniture manufacturers: Calligaris, Nobia, HSL, Howdens, Molteni\&C.

The selection of the automotive and furniture manufacturers was made according to the available analysis and reports. For the automotive industry, we used statistics for the year 2018 (Bekker, 2019). From the top best-selling car manufacturers in Europe in 2018, we have randomly selected five manufacturers. The same principle of randomness was applied for the selection of furniture manufacturers in Europe where the list of firms, analysed in the Centre for Industrial Studies report (CSIL, 2019), was used.

\section{RESULTS}

\section{REZULTATI}

To use the official channels of YouTube and Twitter media, authors have created a list of representation of the selected manufacturers on social media (see Table 1). The list was based on the information obtained from the official web sites of the companies (Calligaris, Nobia, HSL, Howdens, Molteni\&C, Lexus, Renault, SEAT, Peugeot, BMW).

As we can see, Facebook, YouTube and Instagram are the most used social media, while LinkedIn and Pinterest are not so popular.

\subsection{YouTube}

For the content analysis of YouTube, we have used official channels obtained from the manufacturer's official web sites. Each channel was analysed according to the number of subscribers and videos (see Table 2).

There is a significant difference between the car and furniture manufacturers, whereas the number of subscribers for car manufacturers varies between 24400 and 975 000, it is from 9 to 1520 for furniture manufacturers.

Table 1 Social media representation of the selected manufacturers (the X mark is for the social media officially used by the manufacturer)

Tablica 1. Zastupljenost odabranih proizvođača u društvenim medijima (oznaka X odnosi se na društvene medije kojima se proizvođač službeno koristi)

\begin{tabular}{|l|c|c|c|c|c|c|}
\hline \multirow{2}{*}{$\begin{array}{c}\text { Manufacturer } \\
\text { Proizvođač }\end{array}$} & \multicolumn{7}{|c|}{ Social Media / Društveni mediji } \\
\cline { 2 - 7 } & Facebook & Twitter & YouTube & Instagram & LinkedIn & Pinterest \\
\hline Calligaris & $\mathrm{X}$ & $\mathrm{X}$ & $\mathrm{X}$ & $\mathrm{X}$ & & \\
\hline Nobia & & $\mathrm{X}$ & & & $\mathrm{X}$ & $\mathrm{X}$ \\
\hline HSL & $\mathrm{X}$ & & $\mathrm{X}$ & $\mathrm{X}$ & & $\mathrm{X}$ \\
\hline Howdens & $\mathrm{X}$ & & $\mathrm{X}$ & $\mathrm{X}$ & & $\mathrm{X}$ \\
\hline Molteni\&C & $\mathrm{X}$ & $\mathrm{X}$ & $\mathrm{X}$ & $\mathrm{X}$ & $\mathrm{X}$ & $\mathrm{X}$ \\
\hline Lexus & $\mathrm{X}$ & $\mathrm{X}$ & $\mathrm{X}$ & $\mathrm{X}$ & & \\
\hline Renault & $\mathrm{X}$ & $\mathrm{X}$ & $\mathrm{X}$ & $\mathrm{X}$ & $\mathrm{X}$ & \\
\hline SEAT & $\mathrm{X}$ & $\mathrm{X}$ & $\mathrm{X}$ & $\mathrm{X}$ & $\mathrm{X}$ & \\
\hline Peugeot & $\mathrm{X}$ & $\mathrm{X}$ & $\mathrm{X}$ & $\mathrm{X}$ & & \\
\hline BMW & $\mathrm{X}$ & $\mathrm{X}$ & $\mathrm{X}$ & $\mathrm{X}$ & & \\
\hline
\end{tabular}

Table 2 Official YouTube channels data

Tablica 2. Službeni podatci kanala YouTube

\begin{tabular}{|l|l|c|c|}
\hline $\begin{array}{c}\text { Manufacturer } \\
\text { Proizvođač }\end{array}$ & \multicolumn{1}{|c|}{ YouTube Channel/Kanal YouTube } & $\begin{array}{c}\text { Subscribers, } \boldsymbol{n} \\
\text { Broj pretplatnika, } n\end{array}$ & $\begin{array}{c}\text { Videos, } \boldsymbol{n} \\
\text { Broj videa, } n\end{array}$ \\
\hline Calligaris & https://www.youtube.com/user/Calligaris1923 & 1350 & 64 \\
\hline Nobia & https://www.youtube.com/user/NobiaGroup & 9 & 3 \\
\hline HSL & https://www.youtube.com/user/hslchairs & 116 & 42 \\
\hline Howdens & https://www.youtube.com/howdens & 3780 & 92 \\
\hline Molteni\&C & https://www.youtube.com/user/OfficialMolteniDada & 1520 & 164 \\
\hline Lexus & https://www.youtube.com/user/LexusVehicles & 143000 & 501 \\
\hline Renault & https://www.youtube.com/user/renault & 61400 & 1381 \\
\hline SEAT & https://www.youtube.com/seat & 24400 & 590 \\
\hline Peugeot & https://www.youtube.com/peugeot & 68100 & 484 \\
\hline BMW & https://www.youtube.com/user/BMW & 975000 & 911 \\
\hline
\end{tabular}

Subscribers represent the number of subscribers of the manufacturer official YouTube channel and Videos represent the number of the videos published on the manufacturer official YouTube channel. / Pod pretplatnicima se razumijeva broj pretplatnika službenog kanala YouTube, a , video “ označava broj objavljenih videozapisa na službenom YouTube kanalu proizvođača. 
Table 3 Most popular manufacturers' videos on YouTube data

Tablica 3. Videozapisi najpopularnijih proizvođača prema podatcima YouTubea

\begin{tabular}{|l|c|c|c|c|}
\hline $\begin{array}{c}\text { Manufacturer } \\
\text { Proizvođač }\end{array}$ & $\begin{array}{c}\text { Views, } \boldsymbol{n} \\
\text { Pregledi, } n\end{array}$ & $\begin{array}{c}\text { Like, } \boldsymbol{n} \\
\text { Sviđa mi se, } n\end{array}$ & $\begin{array}{c}\text { Dislike, } \boldsymbol{n} \\
\text { Ne sviđa mi se, } n\end{array}$ & $\begin{array}{c}\text { Comments, } \boldsymbol{n} \\
\text { Komentari, } n\end{array}$ \\
\hline Calligaris & 114687 & 166 & 12 & 2 \\
\hline Nobia & 1325 & 1 & 0 & 0 \\
\hline HSL & 517 & 3 & 2 & 3 \\
\hline Howdens & 277 & 191 & 13 & 0 \\
\hline Molteni\&C & 451 & 37 & 8500 & 1352 \\
\hline Lexus & 19907096 & 17000 & 55 & 13 \\
\hline Renault & 3724574 & 170 & 2 & 2 \\
\hline SEAT & 746013 & 64 & 173 & 1397 \\
\hline Peugeot & 10593293 & 6700 & 1600 & 1397 \\
\hline BMW & 16921631 & 64000 & 1704 \\
\hline
\end{tabular}

Views represent the number of views of the most popular videos on the manufacturer official YouTube channel, Comments are a count of visitors' comments on the manufacturer official YouTube channel / Pregledi predočuju broj pregleda najpopularnijeg videozapisa na službenom kanalu YouTubea, a komentari označavaju broj komentara posjetitelja na proizvođačevu službenom YouTube kanalu

The data used for the analysis was obtained from the most popular video of the channel. Again, authors analyse data according to the number of views, likes, dislikes and comments for each video (see Table 3 ).

Comparing the absolute values (number of views) of the car and furniture manufacturers' most popular video, we can conclude that there is again a significant difference. A closer look on the percentage of those that like or dislike the video gives us a different result, whereas for Howden the number of views was 451 , around $69 \%$ gave the "Like to this video". The highest percentage of "Likes" for the car producers was given to BMW, and it was just $0.37 \%$.

\subsection{Twitter}

The use of QDA software limited twitter analysis of one batch to:

- Maximum 10000 tweets

- Maximum 7 day period.

Table 4 Number of tweets with the selected keyword during the 7 days

Tablica 4. Broj tvitova s odabranom ključnom riječi tijekom 7 dana

\begin{tabular}{|l|c|}
\hline Manufacturer / Proizvođač & Tweets, $\boldsymbol{n}$ / Broj tvitova, $n$ \\
\hline Calligaris & 28 \\
\hline Nobia & 0 \\
\hline HSL & 0 \\
\hline Howdens & 37 \\
\hline Molteni\&C & 4 \\
\hline Lexus & $\begin{array}{c}\text { more than } 10000 \\
\text { više od } 10000\end{array}$ \\
\hline Renault & $\begin{array}{c}\text { more than } 10000 \\
\text { više od } 10000\end{array}$ \\
\hline SEAT & $\begin{array}{c}\text { more than } 10000 \\
\text { više od } 10000\end{array}$ \\
\hline Peugeot & 4381 \\
\hline BMW & $\begin{array}{c}\text { more than } 10000 \\
\text { više od } 10000\end{array}$ \\
\hline
\end{tabular}

Tweets represents the activity of the users on the manufacturer official Tweeter account - number of published tweets during the monitored period. / Broj tvitova predočuje aktivnost korisnika na službenom Tweeter-računu proizvođača, tj. broj objavljenih tvitova tijekom promatranog razdoblja.
Table 5 Number of tweets from the manufacturers' address during the 7 days

Tablica 5. Broj tvitova s adrese proizvođača tijekom 7 dana

\begin{tabular}{|l|c|}
\hline Manufacturer / Proizvođač & Tweets, $\mathbf{n}$ / Broj tvitova, $n$ \\
\hline Calligaris & 0 \\
\hline Nobia & 0 \\
\hline HSL & $\begin{array}{c}\text { Not applicable } \\
\text { nije primjenjivo }\end{array}$ \\
\hline Howdens & $\begin{array}{c}\text { Not applicable } \\
\text { nije primjenjivo }\end{array}$ \\
\hline Molteni\&C & 0 \\
\hline Lexus & 13 \\
\hline Renault & 52 \\
\hline SEAT & 5 \\
\hline Peugeot & 12 \\
\hline BMW & 58 \\
\hline
\end{tabular}

Tweets represents the number of tweets published by the manufacturer on the manufacturer official Tweeter account during the monitored period. / Broj tvitova obuhvaća broj onih koje je proizvođač objavio na službenom Tweeter-računu tijekom praćenog razdoblja.

As VADER lexicon was used, another limitation was related to tweets in English.

We have collected two data sets:

- Using the name of the manufacturer as a keyword (see Table 4)

- Using the name of the Twitter account (see Table 5).

The data was collected from February 9th 2019 to August 8th 2019.

As well as for YouTube, Twitter results are very different between the industries. Twitter activities on the car manufacturer's official accounts are hardly comparable to the activities of the furniture manufacturers.

We can see that the furniture manufacturer does not use Twitter as a channel for sharing the information with the customers.

\subsection{Twitter sentiment analysis with the lexicon- based approach}

3.3. Tweeterova analiza dojmova s leksikonskim pristupom

For the lexicon-based sentiment analysis, the text was extracted from tweets. After removing the tweets 
Table 6 Tweets word frequencies

Tablica 6. Učestalost riječi u tvitovima

\begin{tabular}{|l|c|c|c|}
\hline $\begin{array}{c}\text { Manufacturer } \\
\text { Proizvođač }\end{array}$ & $\begin{array}{c}\text { Word frequency, } \boldsymbol{n} \\
\text { frekvencija riječi, } \boldsymbol{n}\end{array}$ & $\begin{array}{c}\text { Go list word frequency, } \boldsymbol{n} \\
\text { Frekvencija riječi popisa Go, } \boldsymbol{n}\end{array}$ & $\begin{array}{c}\text { Ratio Go/Total, } \boldsymbol{n} \\
\text { Omjer Go/ukupno, } n\end{array}$ \\
\hline Lexus & 136 & 48 & 0.28 \\
\hline Renault & 873 & 182 & 0.21 \\
\hline SEAT & 65 & 27 & 0.41 \\
\hline Peugeot & 121 & 27 & 0.22 \\
\hline BMW & 651 & 194 & 0.3 \\
\hline
\end{tabular}

Word frequency represents summary of frequencies of words used in the published tweets on the manufacturer official Twitter account during the monitored period. Go list word frequency is the summary of frequencies of words from the VADER lexicon used in the published tweets, Ratio - compares a frequency of words from the VADER lexicon to the total frequency of the used words. / Frekvencija riječi predstavlja zbroj frekvencija riječi koje se upotrebljavaju u tvitovima objavljenim na službenom Twitter-računu proizvođača tijekom promatranog razdoblja. Frekvencija riječi popisa Go predstavlja zbroj frekvencija riječi iz leksikona VADER koje se navode u objavljenim tvitovima; omjer daje usporedbu frekvencije riječi iz leksikona VADER s ukupnom frekvencijom upotrijebljenih riječi.

that did not fulfil the criteria (keyword or address) and freeing the text of non-applicable graphics, we counted word frequencies in tweets using the Go list dictionary function of the MAXQDA software. VADER lexicon was used as a dictionary. The same operation, word count, was also applied without the VADER lexicon. The results of the word frequencies are presented in Table 6.

For car manufacturers, there is a significant difference between the SEAT and other manufacturers. The tweets on the SEAT official account contained significantly more sentiment words than those of the rest of analysed car manufacturers.

\section{Lexus}

Lexus tweets contained 20 words from the VADER lexicon, where 19 had a positive average value, and one word (limited) had a negative average value.

The five words and emoticons with the highest average positive value were: best, greatest, love, amazing, win.

\section{Renault}

Renault tweets contained 73 words from the VADER lexicon, where 68 had a positive average value and 5 words (demand, limited, no, accidents, mistakes) had a negative average value.

The five words and emoticons with the highest average positive value were: best, love, excellence, great, amazing.

\section{SEAT}

SEAT tweets contained 15 words from the VADER lexicon, all of them with the positive average value.

The five words and emoticons with the highest average positive value were: best, $:^{*}$, kind, care and :).

\section{Peugeot}

Peugeot tweets contained 13 words from the VADER lexicon, where $12 \mathrm{had}$ a positive average value, and one word (broken) had a negative average value.

The five words and emoticons with the highest average positive value were: exciting, glad, *:, easy, sparkle.

\section{$B M W$}

BMW tweets contained 48 words from the VADER lexicon, where 43 had a positive average value and 5 words (cutting, limited, no, difficult, problems) had a negative average value.

The five words and emoticons with the highest average positive value were best, excellence, great, happy, pleasure.

\section{CONCLUSIONS 4. ZAKLJUČAK}

From the very beginning, we have to acknowledge that to compare two very different industries (automotive and furniture) applying just quantitative data brought the expected result: automotive industry representation on social media is incomparable with the representation of furniture industry. Where, for example, the number of subscribers to the official channels on YouTube for the automotive industry ranges between tens of thousands and hundreds of thousands, in the case of furniture industry the number ranges from tens to thousands of subscribers.

Differences can also be observed in the range of supported social media. For the automotive industry, all manufacturers have a Twitter account, for the furniture industry, just three of those selected. A different situation is seen with Pinterest, where most of the furniture producers have an account, while among the car producers, just Lexus has such an account.

Twitter analysis brought similar results. Selected representatives of furniture manufacturers have been mentioned in the tweets during the analysed period from 0 to 37 times. In contrast, in automotive industry, this number ranged from 4381 to more than ten thousand.

Differences have also been observed in activities on the official Twitter accounts, where there was no activity during the analysed period for furniture manufacturers. Therefore, there is no comparison between the content of the tweets applying the sentiment analysis with the lexicon-based approach. It can just be concluded that, for the automotive industry, the content of 
the tweets on the official tweet accounts contained mostly positive words from the VADER lexicon. The word with the highest positive average value was best (four manufacturers), followed by excellence, kind, and care (two manufacturers).

Authors have not expected such significant differences in the use of social media between the selected car and furniture manufacturers considering the fact that selected manufacturers are listed between the top best-selling producers for the year 2018. It is evident that the automotive industry is widely exploiting social media and customers' opinion data for the innovation aimed to fulfil customers' needs and expectations. As for the furniture industry, the potential of the social media influence on consumer behaviour, according to the preliminary research results, was not sufficiently recognised.

The present research will continue with the detailed sentiment analysis using Twitter and YouTube data for a larger group of manufacturers during at least ten discrete periods.

\section{Acknowledgements - Zahvala}

This article was supported by the VEGA project 1/0101/18 and APVV project 15-0681.

\section{REFERENCES}

\section{LITERATURA}

1. Babčanová, D.; Šujanová, J.; Cagáňová, D.; Horňáková, N.; Chovanová, H. H., 2019: Qualitative and quantitative analysis of social network data intended for brand management. Wireless Networks, pp. 1-8. https://doi.org/10.1007/s11276-019-02052-0.

2. Bekker, H., 2019: "2018 (Full Year) Europe: Best-Selling Car Manufacturers and Brands" (online). https://www. best-selling-cars.com/europe/2018-full-year-europebest-selling-car-manufacturers-and-brands/ (Accessed August 27, 2019).

3. Chauhan, K.; Pillai, A., 2013: Role of Content Strategy in Social Media Brand Communities: a Case of Higher Education Institutes in India. Journal of Product \& Brand Management, 22 (1): 40-51. https://doi.org/10.1108/10610421311298687.

4. CSIL, 2019: The Furniture Industry in Europe. October 2019, V ed. Milano Italy, CSIL, pp. 521.

5. Čeněk, J.; Smolík, J.; Svatošová, V., 2016: Marketing on Social Networks: Content Analysis of Facebook Profiles of Selected Czech E-shops. Trends Economics and Management 26 (2): 9-20. https://doi.org/10.13164/trends.2016.26.9.

6. Enginkaya, E.; Y1lmaz, H. 2014: What Drives Consumers to Interact with Brands through Social Media? A Motivation Scale Development Study. Procedia - Social and Behavioral Sciences, 148: 219-226. https://doi.org/10.1016/j.sbspro.2014.07.037

7. Hutto, C. J.; Gilbert, E., 2015: VADER: A Parsimonious Rule-based Model for Sentiment Analysis of Social Media Text. Proceedings of the Eighth International Conference on Weblogs and Social Media, ICWSM 2014, Ann
Arbor, Michigan, USA, June 1-4, 2014 (online). The AAAI Press. http://www.aaai.org/ocs/index.php/ICWSM /ICWSM14/paper/view/8109 (Accessed April 15, 2019).

8. Jothi, P. S.; Neelamalar, M.; Prasad, R. S., 2011: Analysis of social networking sites: A study on effective communication strategy in developing brand communication. Journal of media and communication studies, 3 (7): 234-242 (online). https://www.researchgate.net/publication/267252 690_Analysis_of_social_networking_sites_A_study_on_ effective_communication_strategy_in_developing brand_communication (Accessed September 2, 2019).

9. Karlíček, M.; Král, P., 2011: Marketingová komunikace: jak komunikovat na našem trhu. $1^{\text {st }}$ ed. Praha: Grada.

10. Miller, R.; Lammas, N., 2010: Social media and its implications for viral marketing. Asia Pacific Public Relations, 11 (1): 1-9 (online). https://www.researchgate.net/publication/268200746_Social_media_and_its_implications_ for_viral_marketing (Accessed April 15, 2019).

11. Pawar, K.; Shrishrimal, P.; Deshmukh, R., 2015: Twitter Sentiment Analysis: A Review. International Journal of Scientific \& Engineering Research, 6 (4): 957-964 (online). https://www.researchgate.net/publication/277554 643 Twitter_Sentiment_Analysis_A_Review (Accessed April 15, 2019).

12. Schivinski, B.; Dabrowski, D., 2016: The effect of social media communication on consumer perceptions of brands. Journal of Marketing Communications 22 (2): 189-214. https://doi.org/10.1080/13527266.2013.871323

13. *** 2019: "BMW" (online). https://www.bmw.com (Accessed September 2, 2019).

14. *** 2019: "Calligaris" (online). https://www.calligaris. com (Accessed September 2, 2019).

15. *** 2019: "Howdens" (online). https://www.howdens. com (Accessed September 2, 2019).

16. *** 2019: "HSL" (online). https://www.hslchairs.com (Accessed September 2, 2019).

17. *** 2019: "Lexus" (online). https://www.lexus.com (Accessed September 2, 2019).

18. *** 2019: "MAXQDA" (online). https://www.maxqda. com/ (Accessed January 21, 2019).

19. *** 2019: "Molteni\&C" (online). https://www.molteni.it (Accessed September 2, 2019).

20. *** 2019: "Nobia" (online). https://www.nobia.com (Accessed September 2, 2019).

21. *** 2019: "Peugeot" (online). http://www.peugeot.com (Accessed September 2, 2019).

22. *** 2019: "Renault" (online). https://group.renault.com (Accessed September 2, 2019).

23. *** 2019: "SEAT" (online). https://www.seat.com (Accessed September 2, 2019).

\section{Corresponding address:}

\section{Assist. Prof. JANA ŠUJANOVÁ, PhD}

Institute of Management

University of Ss. Cyril and Methodius in Trnava

Hajdóczyho 1

91701 Trnava, SLOVAK REPUBLIC

e-mail: jana.sujanova@ucm.sk 